\title{
Perubahan Musik Calung Punklung Menuju Musik Modern (Parakan Muncang-Kabupaten Sumedang Tahun 2003-2010)
}

\author{
Riyanti Nurina Fadillah, Widiati Isana \\ Fakultas Adab dan Humaniora \\ Universitas Islam Negeri Sunan Gunung Djati Bandung \\ Email : riantinurinaf2802@gmail.com
}

\begin{abstract}
Calung art is one of the original arts typical of the West Java region and has existed since ancient times, and is commonly used during traditional ceremonies such as traditional ceremonies offered to Dewi Sri or better known as traditional ceremonies "seren taun". In this traditional ceremony the calung art became one of the supporting musical instruments played in the ceremonial process. However, it cannot be denied that this era which is increasingly developing into modern day more or less makes the existence of this calung experience a shift. This study aims to determine how the history of Calung Punklung's music and the process of its change to modern music. The research method used in this study is a qualitative method by collecting sources of literature coupled with sources of interviews and documentation. The analysis technique used is by using heuristic methods, criticism, interpretation and historiography. The results of this study show that the presence of the Calung Punklung music group is an effort to preserve Sundanese culture in the arts in particular. As for the changes made by the Punklung Clung group, this has only just happened in the aspect of bringing the genre of the song that was sung and how to dress when the performance.
\end{abstract}

Keywords: Punklung, Change, Modern Music. 
Perubahan Musik Calung Punklung Menuju Musik Modern | Riyanti Nurina Fadillah, Widiati Isana

\section{Pendahuluan}

Kebudayaan merupakan salah satu hhal yang mempunyai kaitan erat dengan sebuah masayarakat, dari keterkaitan tersbeut membuat keduanya saling berhubungan satu sama lain. Hubungan yang tejalin erta tersebut pada akhirnya membuat sebuah budaya atau kebudayaan ini cenderung dapat diwariskan dari satu generasi menuju ke genrasi berikutnya. Secara epistemologi, kebudayaan berasal dari kata Budhaya yang mempunyai dua arti yaitu adab dan sesuatu yang berhubungan dengan akal. Sedangkan menurut Endaswara, budaya ini merupakan sesuatu yang hidup, berkembang, dan bergerak menuju sebuah titik tertentu. ${ }^{1}$

Indonesia merupakan salah satu Negara yang mempunyai berbagai macam budaya juga etnis di dalamnya. Hal tersebut pula yang memberi pengaruh terhadap banyak ragam jenis kesenian tradisional yang muncul pada akhirnya dan menjadi salah satu warisan budaya nantinya. ${ }^{2}$ Setiap musik tradisional ataupun modern yang muncul ini juga sebelumnya harus melalui beberapa proses diantaranya proses difusi, akulturasi, dan asimilasi antar budaya di dalamnya terlebih dahulu. Perlu kita ketahui bahwa sesuatu yang lokal atau tradisional ini harus dipertahankan, hal itu dikarenakan tidak semua yang bersifat tradisional itu kuno dan harus ditinggalkan, tetapi di dalamnya memnyimpan banyak nilai-nilai sejarah dan budaya yang harus dilestarikan. $^{3}$

Berbicara terkait tradisional, menurut hemat penulis bahwa masyarakat Sunda ini sebagian besar proses kehidupannya selalu bersinggungan dengan yang namanya awi (bambu). Masyarakat Sunda memanfaatkan awi ini sebagai bahan untuk pembuatan alat perkakas rumah tangga juga alat- alat kesenian, seperti pada saat melakukan upacara adat. Sebuah tradisi biasanya akan hadir setelah melalui proses penyesuaian yang dilakukan antara alm dengan masyarakat disekitarnya. Dan tidak dapat dipungkiri bahwa kondisi alam di tataran tanah Sunda ini dikelilingi oleh pohon bambu, maka tidak heran jika sebuah tradisi yang hadir di tanah Sunda ini lebih banyak melibatkan bambu di dalamnya baik itu sebagai alat perkakas ataupun alat pelengkap.

\footnotetext{
${ }^{1}$ Endaswara Suwardi, Metodologi Penelitian Kebudayaan (Yogyakarta: Gadjah Mada University Press, 2003), 1.

${ }^{2}$ L.E. Sunaryo, Komponis, Pemain, Dan Publik (Jakarta: Pustaka Jaya, 1987), 118.

${ }^{3}$ Edi Sedyawati, Get Smart: Ilmu Pengetahuan Alam (Bandung: Grafindo Media Pratama, 2007), 22.
} 
Ada beberapa alat kesenian tradisional Sunda yang terbuat dari bambu diantaranya ada Gendang, Angklung, dan Calung. Ketiga alat musik tersebut merupakan hasil budaya atau tradisi yang ada di tanah Sunda. Aalat musik dari bambu seperti calung ini apabila ditelisk lebih dalam ternyata mempunyai keunikan tersendiri, tidak hanya sebagai alat musik yang dapat dinikmati alunan suara yang dikeluarkannya saja tetapi di dalamnya juga terdapat beberapa tahapan yang harus dilewati sebelum pada akhirnya musik calung ini bisa dijadikan sebagai sebuah hiburan yang dapat dikomersilkan. Tahapan-tahapan tesebut menurut Pursen, diantaranya ada tahapan mistis, tahapan, onotologi, dan tahapan fungsional. ${ }^{4}$ Dari tahapan-tahapan tersebut dipercaya atau tidak harus dilewati terlebih dahulu karena pada dasaranya musik calung ini merupakan music tradisi atau budaya bukan musik yang murni sebagai musik komersil.

Tahapan mistis merupakan tahapan paling awal yang harus dilalui, tahapan ini sering disebut sebagai masa kelahiran daru suatu kesenian itu sendiri. Dalam tahapan mistis ini biasanya suatu kesenian dijadikan sebagai media pertunjukan saat persembahan untuk roh leluhur atau dewa-dewa yang dianggap sakral oleh mereka. Yang kedua adalah tahapan ontologi, dalam tahapan ini perkembangan zaman mulai terjadi dan msuk mempengaruhi proses nalar manusia. Sehingga kesenian tidak lagi hanya dipakai sebagai media pertunjukan saat persembahan untuk roh leluhur saja, melainkan juga dijadikan sebagai media pengekspresian diri. Dalam tahapan ontologi ini masyarakat mulai bisa membedakan antara benda untuk sebuah ritual dan kreasi sehingga untuk benda yang dianggap sakral dapat dijaga kesakralannya. Dan yang terakhir adalah tahapan fungsional, dalam tahapan ini suatu kesenian dijadikan sebagai cara untuk mengartikan kehidupan. Pursen juga mengatakan bahwa di tahapan fungsional ini juga seni tidak lagi hanya menjadi media hiburan pada saat upacara-upacara adat melainkan juga dapat dijadikan sebagai mata pencaharian atau dapat dikatakan sudah bisa dikomersilkan. ${ }^{5}$

Adapun untuk jenis calung yang ada dan berkembang di tanah Sunda ini ada dua jenis yaitu calung rantay dan calung jingjing. ${ }^{6}$ Kesenian musik dari bambu ini juga dulunya digunakan oleh kaum petani pada saat musim

\footnotetext{
${ }^{4}$ Van Pursen, Strategi Kebudayaan (Jogjakarta: Kanisius, 1988), 128.

${ }^{5}$ Pursen, 128.

${ }^{6}$ Yoyok R.M. Siswandi, Pendidikan Seni Budaya 2 SMP (Bandung: Yudistira, 2008), 163.
} 
Perubahan Musik Calung Punklung Menuju Musik Modern | Riyanti Nurina Fadillah, Widiati Isana

panen tiba. Kesenian calungan ini dimainkan pada saat upacara adat persembahan terhadap Dewi Sri karena telah menjaga sawah dan padi mereka sehingga terhindar dari hama yang dapat membuat sawah pun padi mereka rusak.

Perubahan sosio-kultural yang terjadi di masyarakat Sunda ini juga sedikit banyaknya menjadi salah satu faktor adanya peluang kepunahan dari sebuah kebudayaan yang ada semakin besar potensinya. Eksistensi calung sendiri sempat hamper punah seiring perubahan sosio-kultural yang awalnya petani menjadi pekerja industri. Zaman yang semakin berkembang juga membuat banyak terjadinya proses inovasi-inovasi baru yang dilakukan oleh sebagian kelompok musik terhadap musik calung ini dengan harapan agar kesenian calung tetap eksis sekalipun zaman telah berkembang menjadi modern. Salah satu diantara inovasi tersebut adalah dengan adanya musik Calung Punklung ini yang membuat tampilan kesenian calung lebih fresh. Hal itu dikarenkan di dalamnya terjadi proses pengakuklturasian dua budaya anatara budaya Sunda dengan budaya punk.

\section{Metode Penelitian}

Metode penelitian yang dilakukan dalam penelitian ini adalah metode penelitian sejarah, yang di dalamnya terdiri dari beberapa tahapan yaitu heuristik, kritik, interpretasi dan historiografi. ${ }^{7}$ Berikut adalah penjelasan dari tahapan-tahapan tersebut: Heuristik berasal dari bahasa Yunani yaitu heuriskein yang berarti "menemukan". 8 Pada tahapan ini, kegiatan pencarian sumber lebih diarahkan kepada penjajakan, pencarian dan pengumpulan data-data yang sesuai dengan tema penelitian yang dilakukan. Sumber sejarah itu sendiri terbagi menjadi tiga jenis yaitu sumber tulisan, sumber lisan dan sumber benda. ${ }^{9}$ Pada penelitian ini digunakan studi litelatur dan metode wawancara sebagai upaya mengumpulkan sumbersumber yang dibutuhkan untuk penulisan penelitian ini. Tahapan kedua adalah kritik. Dalam tahapan ini terjadi proses penyelidikan atau pengujian terhadap masalah otensitas, kredibelitas atas sumber- sumber yang ditemukan sehingga dapat diketahui otentik atau tidak, serta kredibel atau

\footnotetext{
${ }^{7}$ E. Kosim, Metode Sejarah, Asas Dan Proses (Bandung: Fakultas Sastra UNPAD,
} 1984), 36.

${ }^{8}$ Kuntowijoyo, Metode Penelitian Sejarah (Jogjakarta: Tiara Wacana, 1987), 10.

${ }^{9}$ Sulasman, Teori Dan Metodologi Penelitian Sejarah (Bandung: Pustaka Setia, 2014), 95. 
Perubahan Musik Calung Punklung Menuju Musik Modern | Riyanti Nurina Fadillah, Widiati Isana

tidak. $^{10}$

Tahapan ketiga adalah tahapan interpretasi terhadap fakta. Interpretasi atau penafsiran terhadap fakta sejarah ini sering disebut juga dengan analisis sejarah. Analisis sejarah berarti menguraikan, berbeda dengan sintesis yang berarti menyatukan. Namun, keduanya dipandang sebagai metode-metode utama dalam tahapan interpretasi ini. ${ }^{11}$

Tahapan terakhir dalam metode penelitian sejarah ini adalah tahapan historiografi. Pada tahapan ini terjadi proses pemaparan terhadap hasil penelitian yang telah dilakukan dalam bentuk karya tulis ilmiah. Historiografi itu sendiri mempunyai arti pelukisan fakta-fakta ejarah tentang peristiwa yang telah terjadi pada waktu lalu yang disebut sebagai sejarah. ${ }^{12}$ Pada tahapan ini jenis penulisan yang digunakan adalah jenis penelitian deskripsi analisis yaitu jenis penulisan yang menggunakan faktafakta sumber guna menjawab pertanyaan apa, siapa, dimana, kapan, mengapa dan bagaimana, lalu dituliskan sebagai sebuah kisah yang ditulis secara sistematika dan selaras.

\section{Hasil dan Pembahasan}

\section{A. Kondisi Geografis Parakan Muncang-Kabupaten Sumedang}

a. Letak Geografis

Daerah Sumedang ini dulunya adalah sebuah wilayah kerajaan Sumedanglarang. ${ }^{13}$ Setelah kerajaan Sunda yang berpusat di wilayah Pakuan Padjadjaran runtuh pada tahun 1957, kerajaan Sumedanglarang yang saat itu berada dibawah pimpinan Prabu Geusan Ulun berniat untuk menggantikan posisi kerajaan Sunda yang dirasa sudah menuju masa kehancurannya. Ditengah kondisi kerajaan Sunda tengah terpuruk ini, Prabu Geusan Ulun mnegangkat dirinya sebagai raja nalendra dengan mendapat dukungan dari empat sesepuh/petinggi yaitu Embah Jaya Perkosa, Embah Terong Peot, Embah Kondang Hapa dan Embah Nanggan. ${ }^{14}$ Seiring berjalannya waktu, kini wilayah kerajaan Sumedanglarang ini telah berubah

${ }^{10}$ Kuntowijoyo, Metode Penelitian Sejarah, 13.

${ }^{11}$ Kuntowijoyo, Pengantar Ilmu Sejarah (Jogjakarta: Bentang, 1999), 103-4.

${ }^{12}$ Ismaun, Sejarah Sebagai Ilmu (Bandung: Historia Utama Press, 2005), 23.

${ }^{13}$ R. M. Abdullah Kartadibrata, Silsilah Leluhur Sumedang (Sumedang: Yayasan Pangeran Sumedang, 1998), 1-2.

${ }^{14}$ Nina Herlina Lubis, Tradisi Dan Tranformasi Sejarah Sunda (Bandung: Humaniora Utama Press, 2000), 42. 
menjadi sebuah wilayah Kabupaten di bawah pemerintahaan yang dipimpin oleh seorang Bupati.

Secara geografis, Kabupaten Sumedang ini terletak pada posisi $60^{\circ}$ 34' 46' $18^{\prime \prime}$ - $7^{\circ} 00^{\prime}$ 5.25" Lintang Selatan dan berada di titik $107^{\circ} 01^{\prime}$ 45.63" - $108^{\circ} 12^{\prime}$ 59.04" Bujur Timur. Ibukota dari Kabupaten Sumedang saat ini terletak di daerah kecamatan Sumedang Utara, selain itu Kabupaten Sumedang ini juga mempunyai 26 kecamatan dan kurang lebih ada sekitar 100 desa yang termasuk menjadi bagian dari wilayah Kabupaten Sumedang. Secara administratiif wilayah Kabupaten Sumedang ini berbatasan dengan wilayah-wilayah berikut: ${ }^{15}$

- Sebelah Timur

- Sebelah Utara

- Sebelah Barat

- Sebelah Selatan
: Kabupaten Majalengka

: Kabupaten Indramayu

: Kabupaten Bandung

: Kabupaten Garut

Wilayah Parakan Muncang merupakan bagian wilayah yang masuk ke dalam kecamatan Cimanggung , Kabupaten Sumedang dan menjadi salah satu daerah dengan cakupan wilayah teritorialnya sangat luas sekali. Karena wilayahnya yang luas ini pada akhirnya membuat wilayah Parakan Muncang ini dilakukan pemekaran menjadi dua wilayah desa yang diakui hingga saat ini yaitu Desa Sindangpakuon dan Desa Sindang Galih. Desa Sindangpakuon ini enempati wilayah bagian Parakan Muncang dimasa dulunya, sehingga tidak heran apabila Desa Sindangpakuon ini masih sering kali disebut sebagai wilayah Parakan Muncang. ${ }^{16}$

\section{b. Tofografi}

Kabupaten Sumedang merupakan suatu daerah dengan kontur wilayah yang dimilikinya adalah berbukit dan pegunungan, dengan ketinggian tempat berada di antara $25 \mathrm{~m}-1.667 \mathrm{~m}$ dpl. Berdasarkan data Kecamatan Cimanggung Dalam Angka Tahun 2014 yang dikeluarkan oleh Badan Pusat Statistik (BPS) Kabupaten Sumedang ini pada tahun 2013 Desa Sindangpakuon memiliki status sebagai desa perkotaan dengan klasifikasi sebagai desa swadaya madya (desa yang memenuhi kebutuhannya dengan mengadakan sendiri). Sedangkan jika dilihat secara tofografi, Desa Sindangpakuon ini berada di kawasan dengan bentuk penrmukaan tanah

${ }^{15}$ Lubis, 42.

${ }^{16}$ Tim Penyusun, Kabupaten Sumedang Dalam Angka (Sumedang: Badan Pusat Statistik Kabupaten Sumedang, 2014), 20. 
Perubahan Musik Calung Punklung Menuju Musik Modern | Riyanti Nurina Fadillah, Widiati Isana

berupa hamparan, dan mempunyai ketinggian diantara $6921 \mathrm{~m} \mathrm{dpl.}{ }^{17}$

Desa Sindangpaku ini juga tercatat bahwa di dalamnya terbagi menjadi empat wilayah dusun dengan jumlah Rukun Warga (RW) dan Rukun Tetangga (RT) masing-masing berjumlah $12 \mathrm{RW}$ dan 50 RT. Adapun untuk luas wilayah yang di milikinya, Desa Sindangpakuon ini memiliki luas wilayah sebesar 125,27 hektar.

\section{B. Kondisi Sosial Budaya, Ekonomi dan Kepercayaan Masyarakat Parakan Muncang Kabupaten Sumedang}

a. Kondisi Sosial Budaya Parakan Muncang-Kabupaten Sumedang Budaya adalah salah satu cara berkembang yang dimiliki oleh sekelompok orang yang nnatinya akan diwariskan dari satu generasi ke generasi selanjutnya secara turun temurun. Selain itu, budaya juga merupakan salah satu pola hidup yang menyeluruh dengan mempunyai sifat yang abstrak, kompleks, dan luas sebagaimana yang dikatakan oleh Koentjaraningrat bahwa kebudayaan adalah seluruh sistem gagasan milik diri manusia dengan belajar. ${ }^{18}$

Kebudayaan merupakan modal dasar dalam melandasi pembangunan yang akan dilaksanakan oleh budaya itu sendiri, karena warisan budaya yang bernilai luhur ini juga disebut sebagai dasar pembangunan budaya. Kabupaten Sumedang dalam pembangunan budaya khususnya kesenian ini melakukan pembiam seara berkelanjutan terhadap berbagai kelompok kesenian yang ada agar tetap lestari dan berkembang. Pemerintah terus memberikan pembinaan terhadap kelompok dan organisai tersebut sebagai salah satu pengupayaan agar nilai budaya leluhur yang terkandung di dalam kesenian ini tetap terjaga kelestariannya sehingga dapat dinikmati oleh generasi selanjutnya. ${ }^{19}$

Di Parakan Muncang-Kabupaten Sumedang ini sendiri masih menjaga dan sangat melestarikan kebudayaan yang memeliki nilai sejarah dan nilai-nilai budaya leluhur. Hal itu terbukti lewat acara-acara kesenian tradisionalnya yang masih banyak diminati oleh masyarakatnya sekalipun dizaman yang sudah modern ini. Kesenian tradisonal yang biasa menjadi

${ }^{17}$ Tim Penyusun, Katalog Badan Pusat Statistik Kabupaten Sumedang Tahun 2014 (Sumedang: Badan Pusat Statistik Kabupaten Sumedang, 2014), 18.

${ }^{18}$ Koentjaraningrat, Sejarah Teori Antropologi 1 (Jakarta: UI Press, 1987), 109.

${ }^{19}$ Disparbudpora Sumedang, "No Titl," accessed April 5, 2020, www.disparbudpora.sumedangkab.go.id. 
pertunjukannya pun beragam mulai dari kesenian reog, kesenian calungan, dan bahkan sampai musik Calung Punklung yang saat ini mulai dikenal masyarakat. ${ }^{20}$

b. Ekonomi Masyarakat Parakan Muncang-Kabupaten Sumedang

Apabila dilihat berdasarkan kelas status ekonomi, masyarakat Parakan Muncang- Kabupaten Sumedang ini tentunya sangat beragam karena berasal dari latar belakang yang berda-beda pula mulai dari kelas bawah, kelas menengah dan kelas atas. Mata pencaharian masyarakat Parakan Muncang-Kabupaten Sumedang ini juga sangat beragam, mulai dari petani, peternah, buruh pabrik hingga karyawan industri tekstil yang beada di wilayah Kabupaten Bandung selaku salah satu wilayah perbatasan yang dengan wilayan Parakan Muncang-Kabupaten Sumedang. ${ }^{21}$

Dapat ditarik kesimpulan bahwa kondisi ekonomi masyarakat di Parakan Muncang-Kabupaten Sumedang ini sangat beragam baik secara kelas sosial, strata ekonomi, maupun dalam mata pencaharian. Di samping itu, pada hakikatnya masyarakatnya masih menjungjung tinggi nilai budaya dan senantiasa terlibat dalam pelestarian, sekalipun berbeda latar belakang ekonomi.

c. Kepercayaan Masyarakat Parakan Muncang-Kabupaten Sumedang

Meskipun hampir sebagian besar masyarakat di Parakan MuncangKabupaten Sumedang ini menganut agama Islam sebagai agama kepercayaanya, hal tersebut tidak menjadikan mereka radikal ataupun sebagainya. Sebab di satu sisi lain dalam beberapa tradisi terutama kesenian lokal beberapa nilai budaya leluhur yang ada di dalam kepercayaan orang terdahulu juga masih dilestarikan tetapi tidak diyakini. Adapun tujuan dari pelestarian nilai-nilai budaya leluhur ini adalah untuk tetap menjaga nilai kesejarahan yang terkandung di dalamnya ditengan kemodenitasan saat ini. $^{22}$

\section{Sejarah Asal Usul Musik Calung Punklung Di Parakan Muncang- Kabupaten Sumedang}

${ }^{20}$ Andi S, Wawancara, tanggal 02 Maret 2020 di Parakan Muncang, Kabupaten Sumedang.

${ }^{21}$ Ibeng, Wawancara tanggal 10 Maret 2020 di Parakan Muncang-Kabupaten Sumedang.

22 Wawancara bersama Oman tanggal 10 Maret 2020 di Parakan MuncangKabupaten Sumedang. 
Perubahan Musik Calung Punklung Menuju Musik Modern | Riyanti Nurina Fadillah, Widiati Isana

\section{a. Asal Usul Kesenian Calung Punklung}

Kesenian calung atau calungan merupakan salah satu seni pertunjukan yang biasa dimainkan oleh kaum ploretar seperti orang-orang kelas menengah ke bawah dan oara petani. Seni pertunjukkan calung ini dimainkan oleh beberapa personil dengan setiap personilnya memegang satu alat musik yang berbahan dasr dari kayu. Lagu-lagu yang biasa dibawakannya juga adalah lagu-lagu Sunda atau kakawihan dengan diselengi hiburan candaan di tengah-tengah membawakan lagunya. ${ }^{23}$

Kata calung sendiri mempunyai dua arti yaitu calung sebagai wadirta (alat karawitan) dan calung sebagai seni pertunjukan. Maksud arti dari calung sebagai wadirta ini adalah dikarenakan calung dimainkan pada saat mengiringi seorang juru kawih menembangkan kakawihannya. Begitu juga dengan calung sebagai seni pertunjukkan, hal itu dikarenakan calung dapat mementaskan dirinya sendiri tanpa di bantu oleh kesenian lainnya sebagai pelengkap sehingga dapat dijadikan sebagai media hiburan yang dapat dinikmati. ${ }^{24}$

Kesenian calung yang hidup dan berkembang di masyarakat saat ini adalah calung dalam bentuk seni pertunjukkan (hiburan yang bersifat tontonan) dan tak jarang melupakan penegrtian calung lainnya yaitu sebagai wadirta dalam karawitan. Seni pertunjukkan yang berkembang ini juga pada umumnya masih menggunakan alat-alat musik yang terbuat dari bambu dengan aransemen bunyi nada yang tepat pada setiap bilah bambunya sehingga menghasilkan suara yang harmonis. Jenis alat musik calung yang biasa digunakan dalam sebuah pertunjukan ini ada jenis calung jingjing dan calung rantay dengan ditambah satu alat pelengkap bernama kosrek. $^{25}$

Seiring berkembangnya waktu, kesenian calung ini mengalami perubahan dalam perkembangan yang dilaluinya sehingga tidak lagi hanya digunakan pada saat acara- acara resmi seperti upacara adat saja, melainkan sudah menjadi salah satu kesenian yang dapat dikomersilkan. Berbagai kreasi dan inovasi dilakukan oleh setiap kelompok kesenian calung ini guna

${ }^{23}$ Atik Supandi and Dkk, Ragam Cipta Mengenal Seni Pertunjukan Daerah Jawa Barat, ed. CV. Sampurna (Bandung, 1994), 36.

${ }^{24}$ Budi Rahayu Tamsyah and Dkk, Kamus Lengkap Sunda-Indonesia, IndonesiaSunda, Sunda-Sunda (Bandung: CV. Pustaka Setia, 1996), 28. 5 .

${ }^{25}$ Asep Syaefullah and Pandi Upandi, Calung (Bandung: Aneka Cipta Karya, 2007), 
tetap menarik perhatian dan mendapat tempat dihati para penontonnya serta agar tidak kalah saing dengan kelompok lainnya. ${ }^{26}$

Musik Calung Punklung hadir sebagai salah satu cara untuk menjaga kelestarian budaya Sunda agar tetap terjaga ditengah zaman yang semakin modern ini. Di samping itu, agara citra kesenian calung yang identic kuno ini dapat berubah sehingga bisa dinikmati oleh banyak kalangan termasuk anak muda. Kesenian Calung Punklung ini sendiri mulai muncul dan berkembang di Parakan Muncang-Kabupaten Sumedang ini pada sekitar tahun 2003. Berawal dari niat untuk menjadi sarana pelestarian budaya yang ada di daerah tersebut ternyata mendapat respon yang cukup baik dan dapat dinikmati oleh masyarakat sekitar meskipun tidak dapat dipungkiri bahwa pro dan kontra hadir mengiringi dalam setiap perjalanannya. ${ }^{27}$

b. Teknik Memainkan Kesenian Calung

Teknik baku atau dasar memainkan calung ini adalah dengan cara dipukul menggunakan alat pukul (ditakol). Tangan kiri memegang sematnya dan tangan kanan memukul barang-barang lainnya yang sesuai dengan nada yang dimainkan. Bagian yang dipukul ini adalah bagian depan (beungeut) sedangkan yang dipukul tengah-tengah antara ujung puhu dengan lubang simpul pada bagian congo. Kecuali calung jongjrong yang terdiri dari dari dua semat yang dipukul pada bagian congo. Hal tersebut dimaksudkan agar dapat menghasilkan bunyi yang nyaring dan bersih. ${ }^{28}$

c. Kondisi Musik Calung Punklung Di Parakan MuncangKabupaten Sumedang Tahun 2000-an

Menjelang tahun 1990-an musik calung tradisional di Parakan Muncang- Kabupaten Sumedang ini mulai mengalami masa kemunduran. Hal itu dikarenakan mulai hadirnya musik dangdut yang mewarnai dunia hiburan ditengah masyarakat. Dimasa kejayaannya musik calung ini mampu menghadirkan jumlah penonton yang besar dalam setiap kali pertunjukkan. ${ }^{29}$

${ }^{26}$ Kurnia, Deskripsi Kesenian Jawa Barat (Bandung: Diinas Kebudyaan dan Pariwisata, 2003), 32. Sumedang

${ }^{27}$ Sahlefi, Wawancara, tanggal 17 Desember 2019, di Parakan Muncang-Kabupaten

${ }^{28}$ Syaefullah and Upandi, Calung, 11-12.

${ }^{29}$ Yoyo S, Wawancara, tanggal 02 Februari 2020, di Parakan Muncang-Kabupaten Sumedang. 
Kehadiran musik dangdut di Indonesia ini mau tidak mau sedikit banyaknya membuat musik calung mengalami pergeseran tempat sehingga tidak lagi menjadi primadona masayarakat. Dan tidak dapat dipungkiri bahwa hal tersebut berdampak terhadap kelestarian musik calungyang semakin tergeser. Adanya musik Calung Punklung ini besar harapan ditaruh terhadapnya, agar kelestarian musik calung ini tetap terjaga sekalipun dengan kemasan yang berbeda dari umumnya. ${ }^{30}$

\section{Sejarah Masuknya Punk Di Kabupaten Sumedang-Jawa Barat}

a. Sejarah Masuknya Punk Di Jawa Barat-Kabupaten Sumedang

Punk berasal dari sub-budaya yang lahir di London, Inggris. Pada awalnya kelompok punk ini selalu dikacaukan oleh golongan Skinhead. Namun sejak tahun 1990- an, para punkers ini mulai menyebar di bagian wilayah dunia lainnya. Salah satu yang mulai terdampak oleh adanya kelompok punk yang berasa dari Inggris ini adalah Negara Amerika dan mulai semakin merajalela kehadirannya ke wilayah lain di tahun tersebut. ${ }^{31}$ Punk juga dapat diartikan sebagai jenis musik yang lahir di awal tahun 1970-an.

Selain itu, punk juga diartikan sebagai ideology hidup yang mencakup berbagai aspek kehidupan semisal aspek sosial dan politik. Gerakan anak muda yang diawali oleh anak-anak kelas buruh ini ulai menunjukkan eksistensinya ke beberapa negara dibelahan dunia lainnya selain negara Inggris dan Amerika. ${ }^{32}$

Waktu yang terus bergulir ini membuat eksistensi punk tidak lagi hanya ada di negara Eropa saja, melainkan sudah mulai masuk di beberapa negara Asia salah satunya adalah negara Indonesia. Sebagaimana kita tahu bahwa Indonesia merupakan salah satu negara berkembang yang mempunyai penduduk terbanyak di dunia ini tidak lantas membuat fenomena punk mengalami kesulitan dalam perkembangannya. Di awal perkembangannya, fenomena punk di Indonesia ini diadaptasi dari gaya hidupnya. ${ }^{33}$ Sumedang.

${ }^{30}$ Yoyo S, Wawancara, tanggal 02 Februari 2020, di Parakan Muncang-Kabupaten

${ }^{31}$ Ahmad Yunus, "Komunitas Punk Bandung: Dari Gaya Hidup, Musik, Hinga Pergaulan Politik," Pantau 3 (2007): 4.

${ }^{32}$ Felix Havoe, Punk: Sebuah Cabang Budaya Atau Budaya Perlawanan (Jakarta: Celaka13 Press, 2001), 2.

${ }^{33}$ John Martoyo, PUNK! Fesyen-Subkultire-Identitas (Jogjakarta: Halilintar Books, 2008), 28. 
Menjelang tahun 1998, fenomena punk semakin berkembang seiring merebaknya semangat perlawanan terhadap pemerintah Orde Baru yang saat itu sedang memerintah. Setelah masa Orde Baru selesai, sedikit demi sedikit Indonesia mulai terbuka terhadap paham-paham yang sebelumnya dipandang sebelah mata salah satunya seperti terhadap kelompok punk ini. Pada masa ini juga mulai muncul majalah tentang punkzine yang diterbitkan untuk membangun interaksi antar komunitas punk yang ada di Indonesia. Disamping itu, mulai terlaksakna juga perilisan album bank punk di Indonesia. ${ }^{34}$

Sama halnya dengan wilayah di Indonesia bagian lain, kehadiran punk di Kabupaten Sumedang ini juga pada awalnya membuat pro dan kontra di kalangan masayrakat. Terlebih citra diri dari komunitas punk ini sendiri yang sudah terlanjur dipandang sebelah mata karena berdampak kurang baik terhadap lingkungan sekitar. Lokasi daerah Parakan Muncang yang bisa dibilang cukup strategis karena menjadi penghubung antara Kabupaten Sumedang dengan Kabupaten Bandung ini mau tidak mau menjadi salah satu tempat transit anak-anak punk yang melintas dijalanan. Sedangkan wilayah Bandung ini menjadi central eksistensi punk. ${ }^{35}$

b. Jenis Atau Ragam Punk

Dengan berkembangnya punk dari waktu ke waktu dan pasang surut yang dilaluinya, pada akhirnya membuat punk ini terbagi menjadi beberapa jenis atau ragam aliran punk. Dan diantara ragam jenis aliran punk ini adalah sebagai berikut:

1) Anarcho Punk

2) Crust Punk

3) Glam Punk

4) Nazi Punk

5) $\mathrm{Oi}$

6) Queercore

7) Riot Grrrl

8) Scum Punk

9) Ska Punk

10) Skate Punk ${ }^{36}$

${ }^{34}$ Martoyo, 28.

${ }^{35}$ Wawancara bersama Ajat tanggal 15 Maret 2020, di Parakan Muncang-Kabupaten Sumedang.

${ }^{36}$ Widya, Punk Ideologi Yang Disalahpahami (Jogjakarta: Garasi Housw of Book, 


\section{c. Gaya Hidup Dan Penampilan Kelompok Punk}

Untuk mengetahui dan mengenali anak punk ini tidak terlalu sulit, kita cukup melihat dari ciri khasnya dalam berpenampila seperti dari gaya rambutnya yang lebih dikenal dengan sebutan gaya mowhack. Disamping itu, kelompok anak punk ini juga bisa dikenali melalui ciri khas kukunya yang berwarna hitam sehingga membuat penampilannya semakin terlihat tajam. Dari gaya dan cara berpenampilannya inilah membuat sebagian orang yang melihatnya seperti urakan terlebih untuk orang awam yang tidak mengetahui tentang mereka. ${ }^{37}$

Sehingga menurut epnulis, dapat ditarik satu kesimpulan bahwa semua hal yang diperlihatkan lewat tubuh oleh anak punk ini tidak lebih dari hanya untuk mendemonstrasikan ideologi yang mereka pahami. Disamping itu, sekaligus untuk menunjukkan kepada kita bahwa globalisasi berperanan besar dalam penyebaran gaya ke seluruh dunia meskipun tidak dalam waktu yang bersamaan. Globalisasi beserta seluruh perangkat penyebarannya seperti melalui televise, majalah, dan bentuk media massa lainnya yang berimbas kepada peniruan gaya yang sama sekali berbeda dengan konteks awal sejarahnya. Jadi, anak muda atau remaja yang menggunakan penampilan serba Punk di Indonesia ini sangat mungkin terilhami oleh sesuatu yang sangat berbeda dengan generasi punk pendahulu mereka di negara aslinya.

\section{d. Faktor Pendorong Masuk Kelompok Punk}

Dalam suatu kelompok anak muda, senantiasa selalu ada standar nilai yang digunakan sebagai penerimaan untuk masuk ke kelompok tersebut (Sindroma Penerimaan). Standar nilai yang digunakan ini biasanya semisal kesamaan sifat, atau perilaku yang disenangi oleh kaum muda dalam kelompok tersebut agar menambahkan gengsi. ${ }^{38}$ Merujuk dari hasil penelitian yang dilakukan oleh Aldin Adrian, menyebutkan bahwa alasan yang menjadi faktor pendorong anak muda bisa masuk kelompok punkini adalah sebagai berikut:
1) Teman Sebaya
2) Keluarga

2010), 40 .

37 "No Title," accessed April 5, 2020, http://kompas.com/kompascetak/0512/10/humaniora/2275004.html.

${ }^{38}$ Elizabeth Bergener Hurlock, Psikologi Perkembangan: Suatu Pendekatan Sepanjang Rentang Kehidupan (Jakarta: Erlangga, 1980), 28. 
Perubahan Musik Calung Punklung Menuju Musik Modern | Riyanti Nurina Fadillah, Widiati Isana

3) Orang Lain

4) Pengaruh Media ${ }^{39}$

\section{E. Bentuk Penyajian dan Struktur Pertunjukan Calung Punklung}

a. Bentuk Penyajian Calung Punklung

Bentuk penyajian calung yang sering digunakan saat ini oleh kebanyakan orang adalah calung jingjing yang terdiri dari:

1) Pemain; terdiri dari empat orang pemegang alat Calung.

2) Pemain Gending; pelengkap bunyi calung adalah para pemain gending/pemain kendang goong.

3) Tambahan Pemain; pemegang kosrek.

Sedangkan terkait bentuk penyajian Calung Punklung sebenarnya tidak terlalu berbeda jauh dengan calung pada umumnya, yang menjadi perbedaan mencolok terletak pada pembawaan aransemen dalam setiap lagunya. Sehingga pembuatan alat-alat calungnya pun disesuaikan dengan melodi yang akan dimainkan oleh mereka. ${ }^{40}$

b. Struktur Pertunjukan Calung Punklung

1) Sarana
a) Wadirta
b) Tata Rias dan Busana

2) Struktur Atau Unsur Pertunjukan Calung Punklung
a) Gending
b) Sekar
c) Gerak Aktratif
d) Lawakan

\section{F. Musik Calung Punklung Masa Anak Jalanan Dalam Serdadu Bambu}

a. Profil Kelompok Serdadu Bambu

Kelompok Serdadu Bambu merupakan salah satu kelompok yang bergerak dibidang seni musik calung. Adapun yang membedakan antara kelompok ini dengan kelompok lainnya adalah terletak pada konsep calung yang dibawanya. Jika kelompok lain hanya menampilkan calung dengan konsep pada umumnya yang identik dengan musik bambu ditambah hiburan

${ }^{39}$ Aldin Adria, "Punk Sebagai Fenomena Pop Culture Di Yogyakarta” (Gajah Mada University, 2003), 33.

40 Wawancara bersama Sahlefi tanggal 17 Desember 2019 di Parakan MuncangKabupaten Sumedang. 
goyonan yang menjadi selingan ditengah sajian nyanyian lagu-lagu Sunda. ${ }^{41}$

Sedangkan kelompok Serdadu Bambu ini hadir dengan membawa inovasi baru dalam konsep penampilan calung. Dalam Serdadu Bambu ini calung dikemas dengan perpaduan musik punk yang notabenenya cenderung ke arah genre musik rock. Meskipun demikian, Serdadu Bambu ini tetap tidak menghilangkan unsur atau nilai budaya yang ada di dalam calung tradisional pada umumnya. Kelompok Serdadu Bambu ini pada mulanya di inisiasi oleh salah seorang penikmat musik terutama musik tradisional Sunda yang berada di daerah Parakan Muncang-Kabupaten Sumedang, beliau bernama Sahlefi atau yang lebih dikenal oleh masyarakat sekitar dengan sebutan Abah Evi. Tidak dapat dipungkiri dengan zaman yang semakin modern ini mulai bermunculan berbagai genre musik hadir yang mau tidak mau berimbas kepada musik tradisional yang apabila di diamkan akan semakin terkikis dan tidak bersisa. ${ }^{42}$

Kedekatan Abah Evi dengan sekelompok anak punk di daerah Parakan Muncang- Kabupaten Sumedang ini tidak lain dan tidak bukan menjadi cikal bakal dari terbentuknya kelompok Serdadu Bambu ini. Kedekatannya ini pun oleh beliau dimanfaatkan untuk menjadi sarana dalam melestarikan budaya tradisional Sunda dengan melakukan inovasi lewat perpaduan dua budaya yang notabene bertolak belakang antara budaya tradisional Sunda demgam budaya Punk. ${ }^{43}$

Di samping itu, yang melatar belakangi terbentuknya kelompok Serdadu Bambu ini karena adanya rasa ketidak puasan terhadap lingkungan atau kondisi sekitar yang saat ini cenderung terbawa oleh gaya modern. Salah satu dari efek zaman yang semakin modern ini kentara terasa terhadap kalangan anak muda, dengan mulai banyak yang turut serta menjadi anggota punk. Hal itu dikarenakan anggapan bahwa anak muda yang keren dan gaul itu adalah yang menjadi bagian dari anggota punk. ${ }^{44}$

Akan tetapi, tidak dapat dipungkiri bahwa dengan mulai banyaknya anak muda yang masuk dan terjun menjadi anggota punk ini berimbas

${ }^{41}$ Wawancara bersama Sahlefi tanggal 17 Desember 2019, di Parakan MuncangKabupaten Sumedang.

${ }^{42}$ Wawancara bersama Sahlefi tanggal 17 Desember 2019, di Parakan MuncangKabupaten Sumedang.

${ }^{43}$ Wawancara bersama Sahlefi tanggal 17 Desember 2019, di Parakan MuncangKabupaten Sumedang.

${ }^{44}$ Wawancara bersama Sahlefi tanggal 17 Desember 2019, di Parakan MuncangKabupaten Sumedang. 
terhadap budaya sendiri terutama budaya Sunda yang menjadi tempat kelahiran dan tanah leluhurnya ini mulai terlupakan secara sedikit demi sedikit tanpa disadari. Dengan di dasari oleh hal-hal diatas, lahirlah kelopmpok Serdadu Bambu yang tidak lain merupakan salah satu kelompok musik Calung Punklung. Menurut Abah Evi, kelompok Calung Punklung Serdadu Bambu ini berdiri pada tahun 2003 dengan di inisiasi oleh beliau dan beberapa kawanyna. Kelompok Calung Pungklung adalah sebuah gerakan punk yang lahir dengan tujuan untuk mempertahankan budaya lokal khusunya budaya Jawa Barat. Dengan pengakulturasian antara budaya Barat dengan budaya Sunda ini diharapkan dapat menarik simpatik kaum muda untuk kembali tertarik melestarikan budaya Sunda, salah satunya budaya dalam kesenian musik Sunda seperti calung ini. ${ }^{45}$

b. Gaya Hidup Anak Punk Serdadu Bambu

Gaya hidup punklung Serdadu Bambu ini sendiri dipengarui oleh oleh beberapa faktor dengan faktor utamanya adalah musik. Komunitas punklung ini mempunyai rasa kekeluargaan yang tinggi, hal itu tidak terlepas karena kebiasaan mereka yang senang berkumpul sehingga menumbuhkan sifat kebersamaan yang senantiasa ditampilkannya. Frekuensi mereka dalam berkumpul ini sedikit banyaknya mempengaruhi mereka terhadap kesolidan satu sama lain di dalam kelompok. Komunitas punklung lebih senang dengan kebersamaan dalam kesederhanaan, pungklung dalam kelompok Serdadu Bambu ini juga tidak mau di ekslusifkan dalam hal apapun mereka lebih senang dengan kesedehanaan yang sewajarnya. ${ }^{46}$

Sehingga dapat ditarik satu kesimpulan bahwa, gaya hidup anak punk dalam kelompok Serdadu Bambu ini lebih senang dengan kesedrhanaan sekalipun dengan tampilan yang urak-urakan. Selain itu, mereka juga sangat menghargai sebuah perkumpulan yang selalu mereka adakan, karena dengan itu kesolidin mereka akan terbentuk sehingga saat diatas panggung nantinya tidak perlu lagi menciptakan suasana solid yang terkesan tidak natural.

c. Perkembangan Musik Calung Masa Anak Jalanan Dalam Serdadu Bambu

${ }^{45}$ Wawancara bersama Sahlefi tanggal 17 Desember 2019, di Parakan MuncangKabupaten Sumedang.

${ }^{46}$ Wawancara bersama Iyang tanggal 15 Maret 2020, di Parakan MuncangKabupaten Sumedang. 
Sebagaimana kita tahu bahwa dalam setiap perkembangan ini akan ada pasang surutnya. Di awal kehadirannya anak punk ini juga mendapat pro kontra dari masyarakat karena dianggap sebelah mata ketika hendak membuat sebuah komunitas calung punklung ini. Di tahun 2003 setelah melewati berbagai dilema antara tetap mendirikan atau tidak, dengan landasan dan tujuan baik untuk melestarikan dari budaya sendiri itu juga akhirnya mendapat sedikit respon baik dari sekitar sekalipun belum seuntuhnya semua merespon. ${ }^{47}$

Sudah seyogyanya anak muda sekarang ini harus mau menajadi pemeran utama dalam proses pelestarian budaya tersebut. Jika anak mudanya saja sudah tidak mau melestarikan bahkan melupakan budayanya sendiri, lantas siapa yang akan melestarikan budaya tersebut agar bisa sampai kepada anak cucu kita kelak. ${ }^{48}$

Ketika kelompok Serdadu Bambu ini mulai banyak dikenal orang, akhirnya kehadiran dari kelompok Calung Punklung Serdadu Bambu ini mulai melebarkan sayapnya sehingga tidak hanya masyarakat Sumedang atau Bandung saja yang mengenalnya melainkan masyarakat Indonesia juga. Hal itu dibuktikan ketikakelompok Calung Punklung Serdadu Bambu ini mendapat undangan wawancara dan tampil di televisi nasional, salah satunya di Net TV dalam program acara Indonesia Morning Show. ${ }^{49}$

\section{G. Lagu Islami Dalam Musik Calung Punklung}

Pada dasarnya sebagaimana kita tahu bahwa tampilan kelompok anak punk ini terlihat sangat brutal dan mebuat orang selalu memandangnya dengan sebelah mata. Kelompok Calung Punklung ini sebenarnya tidak pernah mengeluarkan secara gamblang atau terang-terangan lagu bernuansa Islami seperti grup lainnya yang identik dengan solawatan atau lirik lagu yang sangat Islami sekali. ${ }^{50}$

Berbeda dengan yang lain Calung Punklung ini lebigh menggunakan metode pemanfaatan penyampaian pesan yang ada di dalam sebuah lirik

\footnotetext{
${ }^{47}$ Wawancara bersama Sahlefi tanggal 17 Desember 2019, di Parakan MuncangKabupaten Sumedang

${ }^{48}$ Wawancara bersama Sahlefi tanggal 17 Desember 2019, di Parakan MuncangKabupaten Sumedang

${ }^{49}$ Wawancara bersama Sahlefi tanggal 17 Desember 2019, di Parakan MuncangKabupaten Sumedang

${ }^{50}$ Wawancara bersama Iyang tanggal 15 Maret 2020, di Parakan MuncangKabupaten Sumedang.
} 
lagu. Penyampaian pesan dari lirik lagunya itulah yang justru menunjukkan bahwa dalam salah satu lagu yang dinyanyikan oleh kelompok Calung Punklung ini mempunyai pesan religi tersembunyi di dalamnya dan itu terdapat di dalam lagu yang berjudul "Belajar Bersama-sama". ${ }^{51}$

\section{H. Proses Perubahan Musik Calung Punklung Menuju Musik Modern (Parakan Muncan- Kabupaten Sumedang Tahun 2003-2010)}

Musik berasal dari bahasa Yunani yaitu musikus yang berasal dari kata muse-muse yang berarti Sembilan dewa. Istilah musikis ini berkembang menjadi seni musik yang nmempunyai arti yaitu sesuatu yang mengandung bunyi dan suara yang indah. Musik adalah sesuatu yang tak tampak tetapikita tahu ia ada, tidak dapat disentuh tetapi dapat dimainkan, tidak dapat dirasa tetapi memberi kesan, tidak dapat dibau sebelum ia mengisi udara dengan keharuman karena musik adalah cara Tuhan mewarnai suara. ${ }^{52}$

Musik calung punklung merupakan salah satu inovasi baru yang hadir dalam dunia musik. Kehadiran musik calung punklung ini membawa angina segar dalam dunia musik calung yang selama ini dikenal kolot dan hanya bisa dinikmati oleh kaum tua saja. Perpaduan dua budaya yang coba disuguhkan ini sedikit banyaknya membawa perubahan pada musik calung di era modern ini. ${ }^{53}$

Salah satu perubahan yang hadir adalah nunsa penampilan calung yang disuguhkan dalam setiap pertunjukkannya kini lebih menarik sehingga dapat menarik penonton dari berbagai kalangan. Tanpa disadari dewasa ini mulai banyak anak muda yang menyukai calung dengan tampilan baru ini. Dan respon positif ini sedikit banyaknya menjadi jawaban atas tujuan daripada dibentuknya calung punklung itu sendiri yaitu untuk melestarikan budaya tradisional Sunda.

Berbicara terkait perubahan bukanlah satu hal yang mudah untuk dilakukan, sebab akan nada berbagai tantangan yang harus dilalui terlebih dahulu. Proses perubahan yang coba dilakukan oleh kelompok Calung

${ }^{51}$ Wawancara bersama Iyang tanggal 15 Maret 2020, di Parakan MuncangKabupaten Sumedang.

52 Jamalus, Pengajaran Musik Melalui Pengalaman Musik (Jakarta: Dirjen Pendidikan Tinggi Proyek Pengembangan Lembaga Pendidikan Tenaga Kependidikan, 1998), 24.

${ }^{53}$ Wawancara bersama Sahlefi tanggal 17 Desember 2019, di Parakan MuncangKabupaten Sumedang. 
Perubahan Musik Calung Punklung Menuju Musik Modern | Riyanti Nurina Fadillah, Widiati Isana

Punklung dalam mengupgrade kualitasnya ini agar dapat diterima oleh seluruh kalangan sudah terjadi sejak lama bahkan sejak awal dibentuknya kelompok Calung Punklung ini. ${ }^{54}$

Dewasa ini sebagaimana kita tahu, bahwa proses perubahan yang coba dilakukan oleh kelompok Calung Punklung ini adalah perubahan menuju musik modern tanpa merubah atau meninggalkan nilai buday tradisional Sunda di dalamnya. Dan proses perubahan itu tidak berjalan dengan mulus karena hadir berbagai pro dan kontra antara tetap dengan konsep tradisional atau dengan inovasi yang lebih baru dalam tampilannaya. ${ }^{55}$

Perubahan musik calung punklung menuju musik modern ini terjadi tidak dalam taraf alat musik yang digunakannya, melainkan pada genre musik yang dibawakannya. Hal itu dikarenakan, agar alat-alat kesenian calung yang sebenanrnya tetap ada sekalipun dengan melodi yang sedikit berbeda dengan melodi musik calung pada umumnya. Calung Punklung hadir dengan musik calung namun lagu-lagu yang dibawakannya tidak terfokus pada lagu-lagu Sunda saja, melainkan pada genre musik rock yang notabene sebagai musik yang selalu dibawakan oleh kelompok anak punk. ${ }^{56}$

Rock dan calung merupakan perpaduan yang sangat menarik, sebaab musik rock ditampilkan dalam melodi calung dengan alat-alat calung yang terbuat dari bambu berbeda ketika musik rock tampil sebagai musik modern seutuhnya dengan alat-alat musik modern juga tentunya. ${ }^{57}$ Sehingga dapat ditarik satu kesimpulan bahwa perubahan yang terjadi dalam musik Calung Punklung menuju musik modern ini terletak pada genre musik yang di bawakannya. Dimana, sebagaimana kita tahu bahwa musik rock ini merupakan salah satu genre musik modern. Dan Calung Punklung ini mencoba melakukan inovasi dalam musik calung dengan membawakan lagu-lagu rock atau lagu-lagu perjuangan kaum proletar tetapi dengan alat musik tradisional calung yang terbuat dari bambu. Untuk menampilkan lagu rock dengan alat musik tradisional bukanlah satu perkara

${ }^{54}$ Wawancara bersama Sahlefi tanggal 17 Desember 2019, di Parakan MuncangKabupaten Sumedang.

${ }^{55}$ Wawancara bersama Sahlefi tanggal 17 Desember 2019, di Parakan MuncangKabupaten Sumedang.

${ }^{56}$ Wawancara bersama Sahlefi tanggal 17 Desember 2019, di Parakan MuncangKabupaten Sumedang.

${ }^{57}$ Wawancara bersama Sahlefi tanggal 17 Desember 2019, di Parakan MuncangKabupaten Sumedang. 
Perubahan Musik Calung Punklung Menuju Musik Modern | Riyanti Nurina Fadillah, Widiati Isana

mudah, karena harus menyesuaikan melodinya dengan yang ada dalam musik rock agar terciptanya harmonisasi yang baik sehingga enak di dengar oleh penonton.

\section{Simpulan}

Berdasarkan hasil analisis dan interpretasi sumber yang penulis lakukan, maka dapat ditarik kesimpulan bahwa:

1. kesenian calung yang berasal dari bambu ini pada awalnya hanya dipakai pada saat upacara adat Seren Tahun (Hasil Panen) terhadap Dewi Sri sebelum akhirnya sekarang menjadi salah satu media hiburan.

2. Seiring berkembangnya zaman, kesenian calung ini hampir terkikis oleh oleh adanya budaya modern ini. Kondisi inilah yang pada akhirnya membuat seorang seniman di Parakan Muncang- Kabupaten Sumedang bernama Sahlefi ini bersama teman-temannya mencoba untuk menyuguhkan sesuatu baru dalam pertunjukkan calung yaitu dengan sentuhan budaya punk sehingga disebutlah Calung Punklung. Calung Punklung ini juga membuat musik calung tidak lagi terkesan kolot dan hanya dapat dinikmati oleh kaum tua saja.

3. Perubahan musik calung punklung dari yang semulanya dari musik tradisional ini mencoba melakukan sebuah terobosan baru dengan menjadi musik modern. Dan tentunya hal itu bukanlah satu hal yang mudah, perubahan yang terjadi di dalam calung punklung ini baru terjadi pada genre musik yang dibawakannya. Dimana meskipun dengan alat musik tradisional yang terbuat dari bambu tetapi lagu yang dibawakannya adalah lagu rock yang notabenenya merupakan genre musik modern.

\section{Daftar Sumber}

\section{Buku dan Internet}

Adria, Aldin. "Punk Sebagai Fenomena Pop Culture Di Yogyakarta." Gajah Mada University, 2003.

Disparbudpora Sumedang. "No Titl." Accessed April 5, 2020. www.disparbudpora.sumedangkab.go.id.

Havoe, Felix. Punk: Sebuah Cabang Budaya Atau Budaya Perlawanan. Jakarta: Celaka13 Press, 2001.

Hurlock, Elizabeth Bergener. Psikologi Perkembangan: Suatu Pendekatan Sepanjang Rentang Kehidupan. Jakarta: Erlangga, 1980. 
Perubahan Musik Calung Punklung Menuju Musik Modern | Riyanti Nurina Fadillah, Widiati Isana

Ismaun. Sejarah Sebagai Ilmu. Bandung: Historia Utama Press, 2005.

Jamalus. Pengajaran Musik Melalui Pengalaman Musik. Jakarta: Dirjen Pendidikan Tinggi Proyek Pengembangan Lembaga Pendidikan Tenaga Kependidikan, 1998.

Kartadibrata, R. M. Abdullah. Silsilah Leluhur Sumedang. Sumedang: Yayasan Pangeran Sumedang, 1998.

Koentjaraningrat. Sejarah Teori Antropologi 1. Jakarta: UI Press, 1987.

Kosim, E. Metode Sejarah, Asas Dan Proses. Bandung: Fakultas Sastra UNPAD, 1984.

Kuntowijoyo. Metode Penelitian Sejarah. Jogjakarta: Tiara Wacana, 1987.

—. Pengantar Ilmu Sejarah. Jogjakarta: Bentang, 1999.

Kurnia. Deskripsi Kesenian Jawa Barat. Bandung: Diinas Kebudyaan dan Pariwisata, 2003.

Lubis, Nina Herlina. Tradisi Dan Tranformasi Sejarah Sunda. Bandung: Humaniora Utama Press, 2000.

Martoyo, John. PUNK! Fesyen-Subkultire-Identitas. Jogjakarta: Halilintar Books, 2008.

"No Title." Accessed April 5, 2020. http://kompas.com/kompascetak/0512/10/humaniora/2275004.html.

Penyusun, Tim. Kabupaten Sumedang Dalam Angka. Sumedang: Badan Pusat Statistik Kabupaten Sumedang, 2014.

—. Katalog Badan Pusat Statistik Kabupaten Sumedang Tahun 2014.

Sumedang: Badan Pusat Statistik Kabupaten Sumedang, 2014.

Pursen, Van. Strategi Kebudayaan. Jogjakarta: Kanisius, 1988.

Sedyawati, Edi. Get Smart: Ilmu Pengetahuan Alam. Bandung: Grafindo Media Pratama, 2007.

Siswandi, Yoyok R.M. Pendidikan Seni Budaya 2 SMP. Bandung: Yudistira, 2008.

Sulasman. Teori Dan Metodologi Penelitian Sejarah. Bandung: Pustaka Setia, 2014.

Sunaryo, L.E. Komponis, Pemain, Dan Publik. Jakarta: Pustaka Jaya, 1987.

Supandi, Atik, and Dkk. Ragam Cipta Mengenal Seni Pertunjukan Daerah Jawa Barat. Edited by CV. Sampurna. Bandung, 1994.

Suwardi, Endaswara. Metodologi Penelitian Kebudayaan. Yogyakarta:

Gadjah Mada University Press, 2003.

Syaefullah, Asep, and Pandi Upandi. Calung. Bandung: Aneka Cipta Karya, 
Perubahan Musik Calung Punklung Menuju Musik Modern | Riyanti Nurina Fadillah, Widiati Isana

2007.

Tamsyah, Budi Rahayu, and Dkk. Kamus Lengkap Sunda-Indonesia, Indonesia-Sunda, Sunda-Sunda. Bandung: CV. Pustaka Setia, 1996.

Widya. Punk Ideologi Yang Disalahpahami. Jogjakarta: Garasi Housw of Book, 2010.

Yunus, Ahmad. "Komunitas Punk Bandung: Dari Gaya Hidup, Musik, Hinga Pergaulan Politik.” Pantau 3 (2007).

\section{Sumber Lisan:}

Ajat, Wawancara, tanggal 15 Maret 2020, di Parakan Muncang Kabupaten Sumedang.

Andi S, Wawancara, tanggal 02 Maret 2020 di Parakan Muncang, Kabupaten Sumedang.

Ibeng, Wawancara, tanggal 10 Maret 2020 di Parakan Muncang Kabupaten Sumedang.

Iyang, Wawancara, tanggal 15 Maret 2020, di Parakan Muncang Kabupaten Sumedang.

Oman, Wawancara, tanggal 10 Maret 2020 di Parakan Muncang Kabupaten Sumedang.

Sahlefi, Wawancara, tanggal 17 Desember 2019, di Parakan Muncang-Kabupaten Sumedang.

Yoyo S, Wawancara, tanggal 02 Februari 2020, di Parakan Muncang Kabupaten Sumedang. 